\title{
Den følelsen
}

\author{
Den følelsen. Når man bare \\ kjenner at det ikke går. Ikke bare \\ lukter det vondt, det er også noe \\ med lydene. Det er liksom noe \\ i luften som gjør det vanskelig \\ å puste. Kvalme.
}

Vet ikke hvor man skal gjøre av hendene eller hvile blikket. Ble det akkurat litt mindre oksygen? Litt kaldere? Er det en bakterie som gjør at det klør i øyet? Den følelsen. Sykehusskrekk.

Jeg er ikke alene. Vi er mange som har det slik. Mange som får den følelsen. Er på sykehuset på det som skal være et hyggelig barselbesøk, men tankene er et helt annet sted. Følelsene skal være positive. Jeg skal føle glede. Smile. Møte blikket. I stedet er hendene så kalde at man skulle tro det var kuldegrader ute. Tar et skritt om gangen. Dørstokkmila er én ting, den elektriske skyvedøren er så mye verre. Varm vind i forgangen som skal fjerne dugg på brillene. En velkomstplakat. En resepsjon med småstressede, men smilende ansikter. Hendene søker mot munnen. Jeg puster som om det skulle være eksamen om få minutter. Gnir hendene. Tenker at jeg må ta meg sammen.
Sier til meg selv at dette klarer jeg. Hvor pysete går det egentlig an å være? Voksen. Føles ikke slik. Den følelsen.

Det verste man kan oppleve er å miste en man er glad i. Jeg fikk min fars dødsdom overlevert på sykehuset. Det var bare jeg, legen og sykehuset. Jeg tenkte at jeg måtte ikke vise at jeg visste det. Spesielt ikke til pappa. Han smilte da jeg kom. Prøvde å reise kroppen for å komme meg i møte, slik han hadde gjort så lenge jeg kan huske. Kroppen hans klarte det ikke denne gangen. Han smilte da jeg dro også. Jeg brøt sammen i trappen. Jeg og den kalde sykehustrappen, og døden.

Uker. Det var så altfor lite tid. Steinene utenfor sykehusvinduet glitret i solen da jeg gikk. Utenfor ventet tåke. Jeg måtte ta meg sammen. Jeg må fremdeles ta meg sammen. Den sykehusklossen får frem den følelsen. Det hjelper ikke at det er en ny verdensborger eller en kjæreste som trenger sykebesøk innenfor. Følelsen slipper ikke taket. Jeg har prøvd å være tøff. Prøvd å møte sykehuset på en god dag. Nærmest bare stikke innom på slump. Den møter meg hver gang. Den er like ved den elektriske skyvedøren ved brilleduggfjerneren, og den følger meg uansett om jeg tar trappen eller heisen. Jeg tar for øvrig aldri den sykehus- trappen mer. Der er det fortvilelse i hvert steg.

Erfaringene mine er døden. Ikke bare pappas, men også andre kjente som er blitt lagt inn for en rutineoperasjon, men som aldri kom ut igjen. Jeg kvier meg alltid til sykehusbesøk. Ikke kan det være spesielt oppløftende å få bes $\varnothing k$ av en som føler seg så ubekvem heller, tenker jeg da. Og holder meg unna så godt jeg kan. Jeg og samvittigheten kjemper om oppmerksomheten min. Ofte er det jeg som vinner, men innimellom blir samvittigheten utfordret av andre. Så står jeg der igjen. Skjelver innvendig mens jeg krangler med meg selv og går inn den elektriske skyvedøren.

Det finnes Facebook-grupper for alt mulig i dag, men ikke for «oss som har sykehusskrekk». Kanskje fordi det finnes flere som meg som ikke sier noe om det til andre før jeg må. Flere som kjemper den innvendige kampen før man klistrer på seg et tykt lag med «jeg er en annen person»gelé. Det lokale sykehuset bør kanskje ufarliggjøre dette via en informasjonsside? For den følelsen sitter i. Lenge.

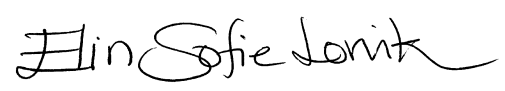

